\title{
Endobronchial growth of metastatic hepatocellular carcinoma 15 years after surgery: a case report
}

\author{
Yu Cai, Shenghong Ju \\ Jiangsu Key Laboratory of Molecular and Functional Imaging, Department of Radiology, Zhongda Hospital, Medical School of Southeast University, \\ Nanjing 210009, China
}

Correspondence to: Shenghong Ju, MD, PhD. Jiangsu Key Laboratory of Molecular and Functional Imaging, Department of Radiology, Zhongda Hospital, Medical School of Southeast University, 87 Ding Jia Qiao Road, Nanjing 210009, China. Email: jsh0836@hotmail.com.

Submitted Jan 20, 2020. Accepted for publication Feb 18, 2020.

doi: 10.21037/qims.2020.02.23

View this article at: http://dx.doi.org/10.21037/qims.2020.02.23

\section{Introduction}

Involvement of the bronchus by metastatic tumors from non-pulmonary sites is an uncommon mode of metastasis. Endobronchial metastases (EBMs) from hepatocellular carcinoma (HCC) are very rare with sporadic literature reports (1-3). The current case report presents a patient with EBM from HCC 15 years after primary surgery.

\section{Case report}

A male patient, 72 years old, presented to our hospital complaining of hemoptysis for 4 days. There was no cough, sputum weight loss or other symptoms. He had undergone hepatectomy 15 years ago for HCC. A history of type 2 diabetes and hypertension was also noted. Serum carbohydrate antigen 21-1 (CA211) level was slightly elevated. Contrast-enhanced computed tomography
(CT) showed an enhancing mass involving the right upper lobe apical segment (Figure 1). There is no other nodules or masses identified in abdominal contrastenhanced CT and magnetic resonance imaging. The bronchoscopy revealed an endobronchial lesion located in the right upper lobe apical segment, which obstructed it almost completely (Figure $2 A$ ). The bronchoscope was not able to pass through it. The pathological examination of the mass showed tumor cells arranged in a nest-like and glandular tube pattern (Figure 2B). Considering the patient's history, bronchoscopy, and histopathology with immunohistochemical staining results, the final diagnosis was metastatic hepatocellular carcinoma.

\section{Discussion}

Lungs is the commonest site of metastases from extra-
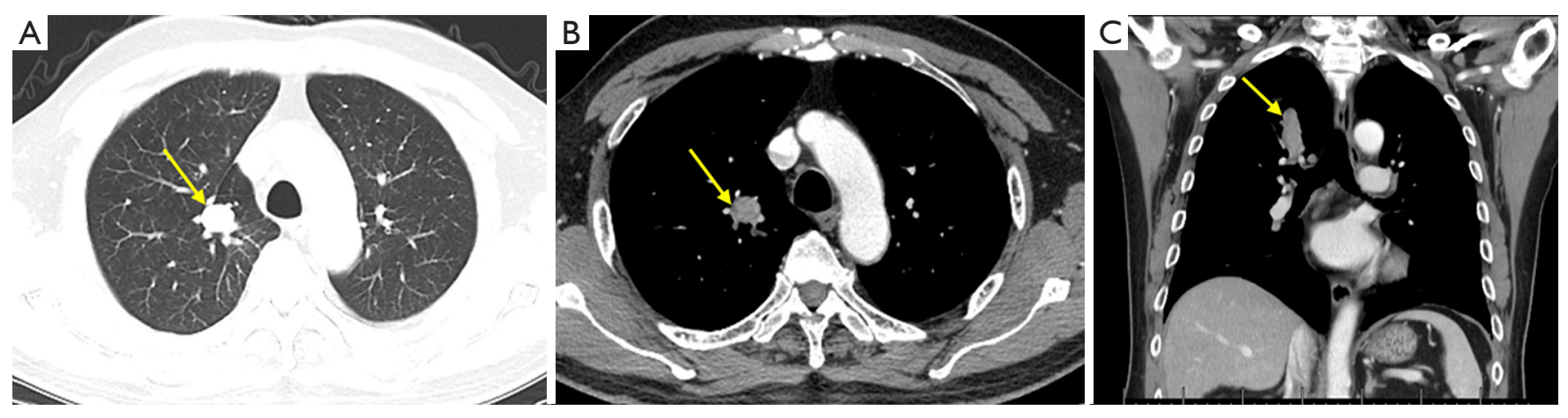

Figure 1 The chest contrast-enhanced CT demonstrates a mass entirely occupying the right upper lobe apical segment (pointed by arrows). 


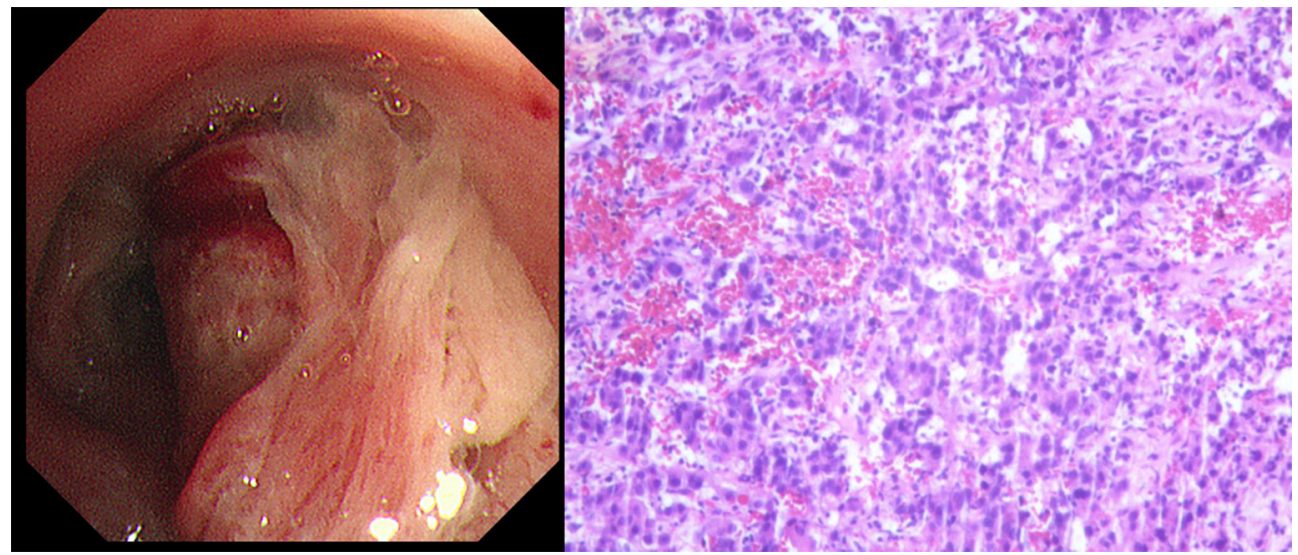

Figure 2 The bronchoscope and pathological examination of the mass. (A) Bronchoscopy showed the endobronchial mass obstructing the right upper lobe apical segment. (B) Hematoxylin and eosin (H\&E) staining of the mass showed massive hemorrhagic necrosis. Tumor cells arranged in a nest-like or glandular tube pattern (magnification, $\times 100$ ).

pulmonary origins. However, endobronchial growth of metastatic tumors is a rare event. Extrapulmonary tumors often associated with endobronchial metastasis include breast carcinoma, colorectal carcinoma, and renal carcinoma. Dyspnea, cough and hemoptysis are the most common symptoms of patient with endobronchial metastases (4). CT findings often show the endobronchial lesion with atelectasis, adenopathy, pulmonary nodules and effusion. It is difficult to distinguish EBM from primary lung cancer by radiographic findings and clinical symptoms. EBM from HCC is very rare that only few cases reported so far. In addition, solitary EBM from HCC after primary surgery has been described in only one case (3). The patient had undergone hepatectomy several years ago and was completely asymptomatic till presented with hemoptysis. In our case, the latency period form primary HCC to endobronchial metastasis is much longer (15 years) than the previous one. Furthermore, bronchus was the only metastatic lesion detected.

\section{Acknowledgments}

Funding: None.

\section{Footnote}

Conflicts of Interest: All authors have completed the ICMJE uniform disclosure form (available at http://dx.doi. org/10.21037/qims.2020.02.23). The authors have no conflicts of interest to declare.

Open Access Statement: This is an Open Access article distributed in accordance with the Creative Commons Attribution-NonCommercial-NoDerivs 4.0 International License (CC BY-NC-ND 4.0), which permits the noncommercial replication and distribution of the article with the strict proviso that no changes or edits are made and the original work is properly cited (including links to both the formal publication through the relevant DOI and the license). See: https://creativecommons.org/licenses/by-nc-nd/4.0/.

\section{References}

1. Camps C, Soler JJ, Juan G, Navarro R, Lloret J, González G. An unusual form of metastasis of hepatocarcinoma: endobronchial metastasis. Rev Esp Enferm Apar Dig 1988;74:155-7.

2. Kido T, Iwanaga T, Takata S, Kaketa Y, Kawanami T, Kido M. A case of solitary endobronchial metastasis of hepatocellular carcinoma. Nihon Kokyuki Gakkai Zasshi 2005;43:422-6.

3. Purandare NC, Pramesh CS, Rangarajan V, Shet T, Shukla PJ, Mistry RC. Hepatocellular carcinoma recurring as isolated endobronchial metastasis 8 years after primary surgery. J Thorac Imaging 2009;24:147-9.

4. Marchioni A, Lasagni A, Busca A, Cavazza A, Agostini L, Migaldi M, Corradini P, Rossi G. Endobronchial metastasis: an epidemiologic and clinicopathologic study of 174 consecutive cases. Lung Cancer 2014;84:222-8.

Cite this article as: Cai Y, Ju S. Endobronchial growth of metastatic hepatocellular carcinoma 15 years after surgery: a case report. Quant Imaging Med Surg 2020;10(4):874-875. doi: 10.21037/qims.2020.02.23 